\title{
Computer aided design of knitted and woven fabrics and virtual garment simulation
}

DOI: $10.35530 / 1 T .070 .06 .1659$

INDRIE LILIANA

MEHMET METE MUTLU

NILAY ORK EFENDIOGLU
TRIPA SIMONA

PABLO DIAZ GARCIA

MIQUEL SOLER

\section{ABSTRACT - REZUMAT}

\section{Computer aided design of knitted and woven fabrics and virtual garment simulation}

Pattern cutting, sizing and fit are major issues for the clothing brands. All fashion companies are interested on how the product will fit their target customers and this involves making samples that eventually will not look or fit as per the desired design. 3D technology solutions are truly the best to deal with the existing needs of clothing manufacturers in order to diminish the costs and time of the sampling process, to improve the quality and reduce the rejects. In this study, the authors used automation techniques like computer pattern design, computer aided fabric production and $3 D$ Simulation software. Two different fabrics (woven and knitted) were designed and produced. Then their material properties which have to be known by the 3D simulation were determined by official and in-house standards. Finally, 3D visualizations of dresses were created by using pattern and material data of the fabrics. By this study we were able to explain the product development route, from fabric design to garment prototype by using computers, for the companies willing to benefit from the advantages of computer aided design and manufacture.

Keywords: 3D, garment design, garment simulation, woven fabric, knitted fabric.

Proiectarea asistată de calculator a țesăturilor și tricoturilor și simularea în spațiul virtual a îmbrăcămintei

Realizarea tiparelor, stabilirea gamei dimensionale și modul de așezare a produselor pe corpul purtătorilor sunt probleme majore cu care se confruntă firmele producătoare de îmbrăcăminte. Toate companiile de modă sunt interesate de modul în care produsele de îmbrăcăminte sunt adaptate la cerinţele consumatorilor, iar acest lucru implică realizarea de mostre care, la final, s-ar putea să nu arate conform design-ului dorit. În sprijinul producătorilor de îmbrăcăminte vin soluțiile tehnologice $3 D$ care au ca scop diminuarea costurilor și a timpului procesului de eșantionare, îmbunătătirea calității produselor şi eliminarea produselor neconforme (refuzate). În acestă lucrare, autorii au utilizat tehnici de automatizare precum designul materialelor, producerea acestora şi simularea 3D a îmbrăcămintei. Două materiale diferite (țesute și tricotate) au fost proiectate și produse. Apoi au fost determinate proprietățile acestora, proprietăți care, alături de tipare, au fost utilizate pentru realizarea simulării 3D a rochiilor. De asemenea, pentru companiile care doresc să beneficieze de avantajele proiectării și fabricării asistate de calculator, a fost prezentat modulvoltare a unui produs de la proiectarea asistată de calculator a materialelor la prototipul îmbrăcămintei.

Cuvinte-cheie: $3 D$, design vestimentar, simularea îmbrăcămintei, țesătură, tricot

\section{INTRODUCTION}

In front of increasingly demanding consumers, who expect variety, low prices and quality products, the CAD/CAM programs (such as 2D patternmaking and $3 \mathrm{D}$ clothing design and modeling) can improve the flexibility in design, productivity and speed to market [1]. According to garment manufacturers and fashion retailers, the pattern cutting, sizing and fit are major issues for the clothing brands. All fashion companies are interested on how the product will fit their target customers and this involves making samples that eventually will not look or fit as per the desired design [2]. Power J. considers that the product development time can go to $70 \%$ in a typical garment life cycle, while the actual manufacture is $30 \%$ [3]. 3D technology solutions are truly the best to deal with the existing needs of clothing manufacturers in order to diminish the costs and time of the sampling process, to improve the quality and reduce the rejects [2].

Virtual garment design and 3D simulation [4-11] have to take into account not only the physical characteristics of the fabric (density, thickness, deformability) but also it has to combine a large spectrum of techniques such as mechanical simulation, collision detection, and user interface techniques for creating garments. The virtual prototyping can be successful only when all specific characteristics of the textile materials and accurate virtual body models to simulate the garment fit are fully taken into account [12]. Assyst Vidya 3D [13] is a leading software for the 3D simulation of apparel and enables the visualization and simulation of collections, with correct body dimension data, original CAD designs and real material parameters. It simulates persons with realistic 
body measurements, volume and movement behavior. It also uses real material parameters, allowing the natural stretch behavior and the structure of a fabric to be checked on the screen. Drape, elasticity and structure correspond to the fabric's natural movement behavior Human, pattern and material interact perfectly for the simulation and the same body measurements/size tables are used in CAD and for the creation of avatars. The simulated $3 D$ garment consists of the sewn 2D CAD pattern pieces, just like in real life.

The first step in our paper was to generate the Argyle pattern designs in Adobe Illustrator. After the design part, the second step was to realize the woven and the knitted fabrics. The woven and knitted samples were produced on a SMIT Textile GS900 Jacquard Loom respectively on a Shima Seiki Knittingmachine. The designs were transposed in these two types of fabrics because the computer-aided woven fabric design has been the first topic in the automation in textile industry [14]. It has been developed to be one of the most effective processes nowadays, meanwhile it is possible to create products through knitting with outstanding characteristics, such as: knitting to shape, great flexibility in production, controlled properties, and excellent formability [15]. The second step was to determine the properties of knitted and woven fabrics (Thickness, Grammage, Stretching, Bending, and Friction) and to convert them to Vidya 3D Software parameters. Simulations were done by using Human Solutions Assyst Vidya 3D software version 20.17.2.31690. The garment was fitted on a virtual mannequin in order to visualize the draping of the knitted and woven fabrics before the manufacturing. The data collected were used as input for material wizard parameters. In addition, the photos of the fabric were taken and their texture was transferred to the software for realistic visualization. The final step was to make the real prototype of woman's dress according to the real body measurement for size 38 . The aim of the study was to make a lab-scale production to explain automation techniques like computer pattern design, computer aided fabric production and 3D simulation software in an apparel product development route. For this purpose, two different kinds of fabrics (woven and knitted) were designed and produced. The material properties required for the 3D simulation software were determined by using various standard and in-house test methods. The measured material data were interpreted to the $3 D$ software considering behaviors of the clothes in the visualization and 3D prototypes of clothes by these materials were obtained. The detailed explanation of methodology will be beneficial for the companies who are going to implement computer aided design and manufacturing into their manufacturing line.

\section{MATERIALS AND METHODS}

\section{Argyle pattern designs}

Taking into account the fashion trends, in the present paper the authors intended to create different Argyle

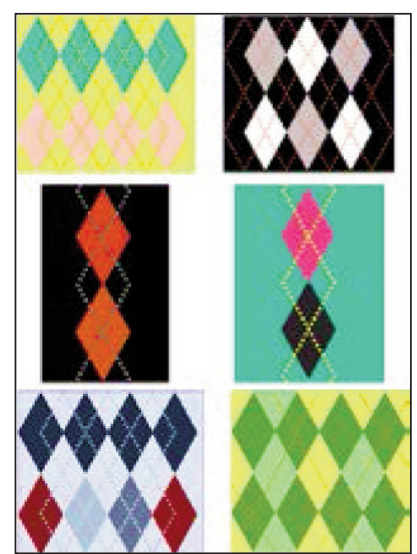

Fig. 1. Argyle Patterns in Adobe Illustrator
Patterns designs, using the instruments of Adobe Illustrator (figure 1). Next step was to make the woven and knitted fabrics.

\section{Woven fabric}

The woven fabric has been weaved on a SMIT Textile GS900 Jacquard Loom (figure 2). This is an appropriate loom for a large variety of applications [16], from garment fabrics to home textiles, terry cloths and technical fabrics. Provided with an electronic jacquard machine Stäubli DX-100 of 1.408 hooks, the harnesses are built in straight tie order, which allows the correct ordering of the yarns for interlacing and thus obtaining the required drawing. Regarding the fabric structure, the width of the loom is $160 \mathrm{~cm}$, and the beam is composed by 9,600 threads, with a set of 60 picks $/ \mathrm{cm}$ in the comb. The count of the warp thread used is polyester 17 TEX, in brown colour. The weft is composed by two different yarns with the same count 12.4 TEX, made of polyester fibre, in different colours in relation 1:1, one sky colour multifilament and the other one is white multifilament colour. The fabric has a weft density of 72 picks/cm and the structure of the fabric is double face by weft. This design has been achieved by combining three different weaving types of the fabric, and with the correct combination of colours of the warp and weft threads. To obtain the complete design, the pattern repeats every $11.4 \mathrm{~cm}$.

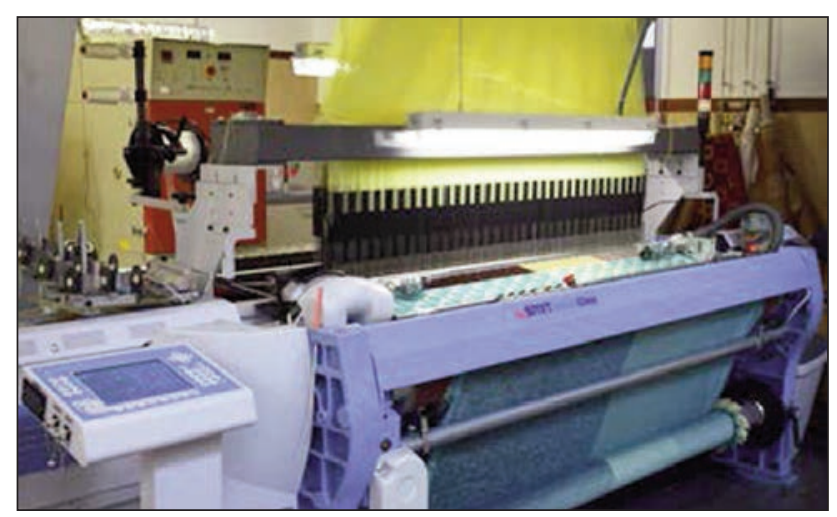

Fig. 2. The fabric made by Smit Textile GS900 Jacquard Loom

\section{Knitted fabric}

The proposed design was transposed into a jacquard knit, made on a Shima Seiki knitting machine. The knits with Jacquard drawings are characterized by large and very large drawings the first step was to decide the size of the pattern or design. Thus, was decided that the drawing ratio should have a width of 
$6 \mathrm{~cm}$ and a height of $24 \mathrm{~cm}$, repeating itself on the entire surface of the knit.

After that was draw on the computer screen, the pattern on a grid, with the help of a specific design program for knitting machines, in which each square will be a stitch (in our case the 'KNIT' program has been used from the manufacturer SHIMA-SEIKI) (figure 3). The design was done drawing in the first phase the ground structure, and on it, the different colours that will form the final drawing are incorporated successively. The colours used for the design are not random, but must be selected from a colour tablet proposed by the software manufacturer, and each colour has a specific meaning. When the stitch design has been completed, the instructions for the machine must be incorporated into the drawing on the screen: speed, take down, yarn feeder used for each colour, stitch quality, cycles, etc.

Once the design is completed and all the commands have been analyzed by the software to detect possible failures, the program generates a file in the machine-language that can be transferred to the knitting machine through a wire from the programming computer, or with the help of an external memory (pen-drive).

After feeding the knitting machine with the yarns used, the actual knitting was performed. The knitwear has a horizontal width of 27 strings $/ 50 \mathrm{~mm}$ and a vertical 25 rows $/ 50 \mathrm{~mm}$, which gives the knitwear the necessary properties to be used in subsequent fabrication of many types of outwear products.

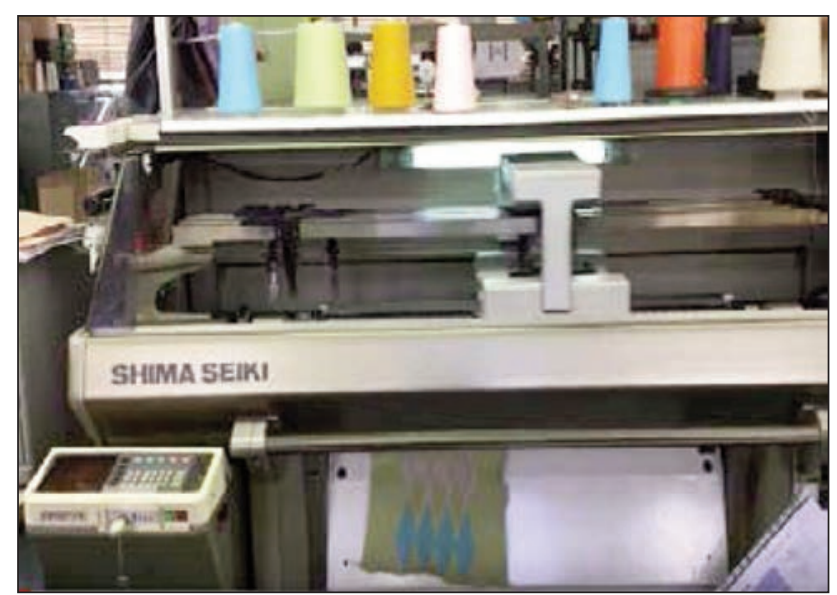

Fig. 3. The knitted fabric made by SHIMA-SEIKI

Determining properties of fabrics and converting them to Vidya 3D Software parameters

Analyzing the mechanical properties can enhance to determine the behaviour of the fabrics during clothing exploitation [17]. Samples of woven fabric and knit obtained were analyzed and subjected to tests that determined the following properties (Thickness, Grammage, Elongation, Bending, and Friction Coefficient).

The thicknesses of test samples were measured by Satra-Thickness gauge according to ISO 2589:2016 (IULTCS/IUP 4standard. The grammage of test samples were measured by Analytical balance according to ISO 3801 standard.

Shimadzu AG-IS Tensile Tester and Trapezium-2 software were used for elongation test according to EN ISO 13934-1 standard. Five samples were taken with the size of $50 \mathrm{~mm} \times 250 \mathrm{~mm}$ per weft, warp and diagonal direction. Clamping width was $50 \mathrm{~mm}$ and clamping length was $200 \mathrm{~mm}$. The test started without any pre-load. Testing speed was $100 \mathrm{~mm} / \mathrm{min}$. In Vidya 3D, to determine the force, the garment fit has to be considered. The closer the garment fits to the body, the higher the value for this parameter. Following forces occur while wearing clothing. Value Explanation: $20 \mathrm{~N} / \mathrm{m}$ : Loose fitting, $40 \mathrm{~N} / \mathrm{m}$ : Tight fitting, $60 \mathrm{~N} / \mathrm{m}$ : Shape wear, $80 \mathrm{~N} / \mathrm{m}$ : Compression wear. Dress model was chosen and thus defined force was selected $20 \mathrm{~N} / \mathrm{m}$. In stress-strain diagram, the elongation at $20 \mathrm{~N} / \mathrm{mm}$ was observed and noted as Elongation \%.

Fabric bending rigidity is one of the most important factors, which has effect on handling, and comfort of apparel; in 1930, the bending behaviour has been explored quite extensively, beginning by Peirce [18]. On the other hand, bending rigidity is one of the most important properties of fabrics and is a key component in deciding fabric handle and drape. It is an important contributor to fabric's formability [19], buckling behaviour [20], wrinkle-resistance [21] and crease resistance [22].

Shirley stiffness tester is used for bending stiffness according to ASTM D1388 standard. The principle of this test is to measure the length of the strip-cut sample with a horizontal angle of $41.5^{\circ}$. The device has a smoothly slippery plate $\mathrm{P}$ on the surface and an $\mathrm{S}$ slider with a rough surface millimeter. Width of $S$ slider is 2.5 centimeters and length is 15 centimeters. In the horizontally placed section of the sample prepared with dimensions of $2.5 \times 15$ centimeters, the sample was allowed to be released from one end while it was allowed to be released by its own weight on the other hand. Observation lines have been drawn on the lateral transparent covers of the device, which pass through the leading edge of the upper plane and make an angle of $41.5^{\circ}$. When the tip of the sample reaches a slope of $41^{\circ}$ below the horizontal, the hanging length is twice the length of the bending length. Bending rigidity was calculated for each sample at the front and back of fabrics. The bending properties of the woven and knitted fabrics govern many aspects of the fabric's performance, such as the hand and drape, and they are an essential part of complex fabrics deformation analysis.

FricTorq device is an improved system for the determination of dynamic friction coefficient. The device is used to determine the dynamic friction coefficient based on the torque of the rotation. For the friction coefficient test, two samples were taken from each sample with the help of the template with the diameter of 13 centimeters. The top plate is removed so that the test sample can be placed in the device. The sample was placed on the centre of the main disc. The sample was compacted onto the main disc by 


\begin{tabular}{|c|c|c|c|c|c|c|}
\hline \multicolumn{7}{|c|}{ THE PROPERTIES OF THE FABRICS } \\
\hline \multirow[b]{2}{*}{ Fabrics } & \multicolumn{3}{|c|}{ Knitted } & \multicolumn{3}{|c|}{ Woven } \\
\hline & & & & & & \\
\hline \multicolumn{7}{|c|}{ Datasheet specifications } \\
\hline Knit type and Weave type & \multicolumn{3}{|c|}{ Jacquard Jersey } & \multicolumn{3}{|c|}{ Plain fabric (Jacquard) } \\
\hline Fibre content & \multicolumn{3}{|c|}{ Acrylic fiber } & \multicolumn{3}{|c|}{ Polyester fiber } \\
\hline Width $(\mathrm{cm})$ & \multicolumn{3}{|c|}{75} & \multicolumn{3}{|c|}{160} \\
\hline Weight $\left(\mathrm{gr} / \mathrm{m}^{2}\right)$ & \multicolumn{3}{|c|}{325.54} & \multicolumn{3}{|c|}{235.90} \\
\hline \multirow[t]{2}{*}{ Thickness (mm) } & \multicolumn{3}{|c|}{1.09} & \multicolumn{3}{|c|}{0.38} \\
\hline & Weft & Warp & Bias & Weft & Warp & Bias \\
\hline Elongation at $20 \mathrm{~N} / \mathrm{m}(\%)$ & 61.2985 & 42.7015 & 39.7565 & 4.09 & 5.1505 & 12.647 \\
\hline Bending (mg.cm) & 443.76 & 625.83 & - & 855.63 & 1247.81 & - \\
\hline Friction Coefficient (Back) & \multicolumn{3}{|c|}{0.65} & \multicolumn{3}{|c|}{0.33} \\
\hline
\end{tabular}

the weight of the press ring itself. Four vertical guides restrict it. The centre disk is placed on the press ring. It must definitely be removed before the start of the test. The contact sensor is placed on the sample so that it enters into the round space on the centre disk and the device is operated. The device gives the kinetic friction coefficient $(\mu)$ value of the sample surface. In Vidya 3D, this data means a friction between avatar and the fabric. Because of that, results of the backside of the fabric were chosen.

The thickness of the knit pattern is much larger than the one weighed because of the way the two types of materials are obtained. This is also reflected in the weights of the two material samples - the knit is heavier than the fabric. The elongation of the two types of material (in all directions) is significantly higher for knit - this is one of the main characteristics that differentiate the two types of fabrics. The higher the thickness of the knit affects its ability to be bent the bending knit value is almost half that of the fabric. The coefficient of friction is much higher in the case of knit - which will favour the occurrence of the piling phenomenon on the products made of these materials. Even though there are significant differences between the properties of the two types of materials, both are suitable for use in the fabrication of a wide range of clothing products.

After these properties were determined, they were converted to Vidya 3D Software parameters. Vidya uses real material parameters to display the natural stretch behavior and structure of the fabrics. Human, pattern and material interact perfectly so that drape, elasticity and structure correspond to natural movement behavior.

The data collected were used as input for material wizard parameters. Simulations were done by using Human Solutions Assyst Vidya 3D software version 20.17.2.31690. The data collected were used as input for material wizard parameters. In addition, photos of the fabric were taken by a DSLR camera and their textures were transferred to the software for realistic visualization. Further on was created the $2 \mathrm{D}$ dress patterns (figure 4).

The flat pattern pieces were placed on a virtual body. Our aim was to place the patterns as close as possible to the body surface and, for this, a manual

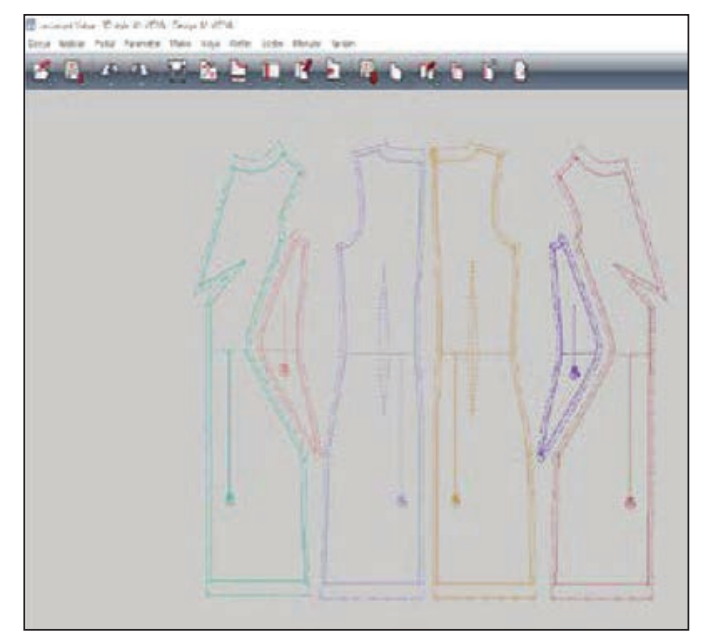

Fig. 4. 2D patterns 


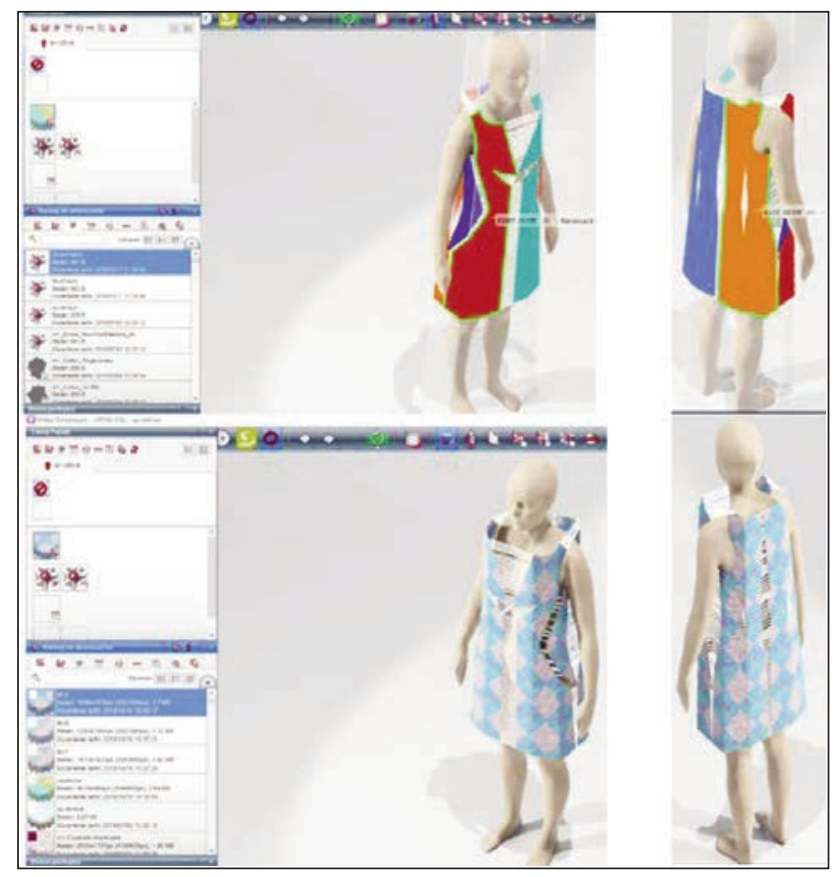

Fig. 5. 2D to $3 \mathrm{D}$ transformation placement with an automatic function was used. Knowing that the seams would bring together the edges of the patterns, it was required to approximate the initial positioning. The space between two seam lines had to be as small as possible in order to get a proper final garment.

The fabrics parameters, and particularly the physical parameters of the knitting and woven texture were adjusted through the garment material wizard panel. There are two categories of parameters in 3D simulation program: global parameters (gravity, collision distance and detection modes) and local parameters (thickness, bending rigidity, friction values and elongation). While global parameters are mainly related with software and how it adjusts the realism in virtualization: local parameters on the other hand are related with the material properties and how the fabric acts in the simulation. The measured fabric parameters of knitted and woven samples were used as input for the garment material wizard panel of the software. Detailed photographs of the samples were taken in well and homogenous-lighted environment,

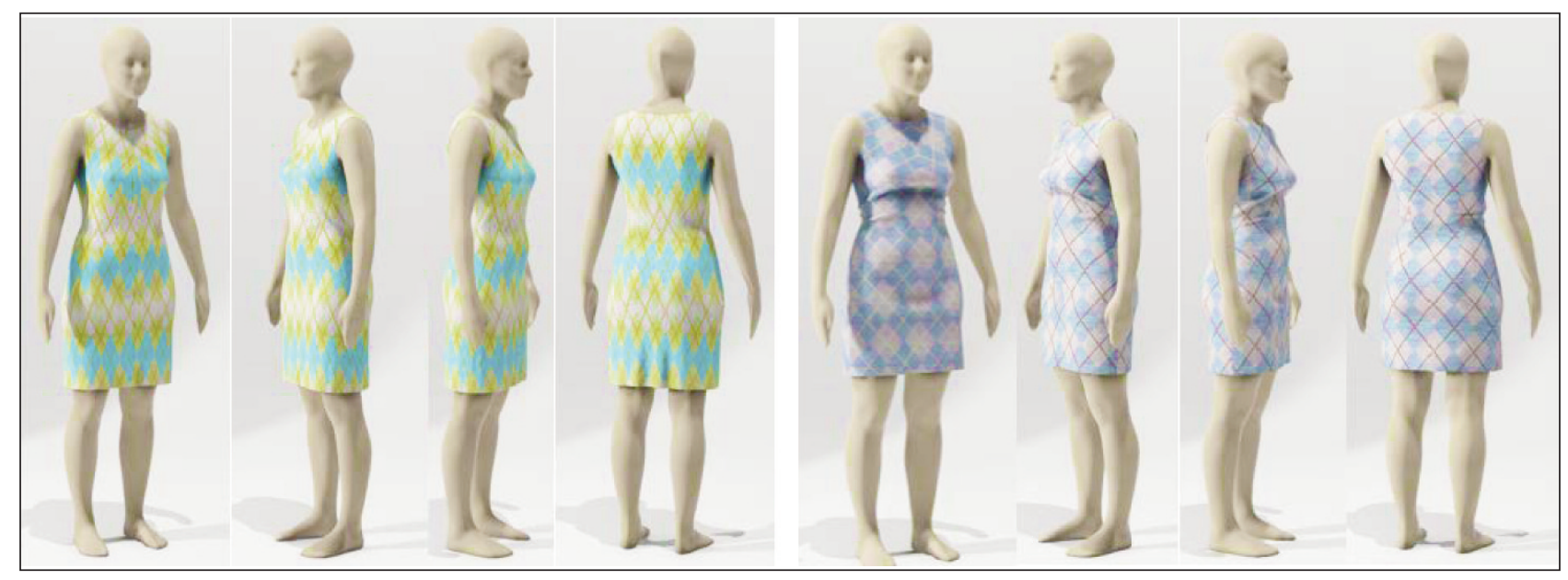

Fig. 6. 3D garments design by using AssystVidya 3D software

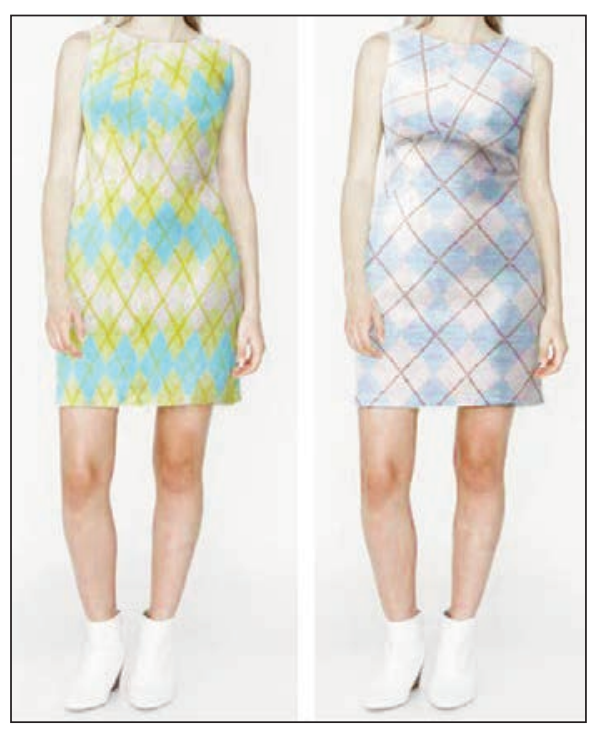

Fig. 7. The final garment they were used as input for the texture panel of the software.

Once the texturing and fabrics parameters were set, the mechanical simulation could be performed in order to observe the "fitting" of the garment. In this way, the surfaces were brought together along the seam lines as shown in figure 5.

After the placement of the patterns around the virtual mannequin, the seaming was executed in order to visualize the virtual product and to simulate fabric drape and fit. Simulation of knitted fabrics can be seen on the left and the woven fabric on the right in figure 6 . The real dresses are shown in figure 7.

\section{CONCLUSIONS}

As a consequence of high-quality clothing demand and strong competition, many manufacturers started to use the automation technology, which enables the 
clothing companies to generate strategy, communicate, and make the whole process quick and precise. Nowadays, the virtual garment simulation is related to an increased speed of the production chain, with great impact on price, on the ability to offer to customers more than two collections in the same year. From the study presented, it can be concluded that the knitted material has a higher thickness and is more voluminous while the woven fabric has more drape and flow resulting from its lower thickness. The knitted loop structure confers high stretch ability and elasticity to the fabric, while the intersection of yarns at right angle gives proper stability and durability to woven fabric. We can say that even though there are significant differences between the properties of the two types of materials analyzed in this paper, both are suitable for use in the design of the dress model proposed in the paper.
3D visualization software allowed us to see and explore the dresses made from woven and the knitted fabrics on a virtual mannequin before the manufacturing. The virtual garment visualization represents an important step in the field of digital design and the apparel manufacturers have shown a special interest in its development. These programs have their own material databases, but apparel companies can also introduce their own materials. The success of this software directly depends on how the material properties and textures are imported into the program which requires experience of the operator. In this study the methods how the material properties were implemented into the program are explained in detail and, by using correct parameters, realistic visualization of dresses were obtained. This automation methodology from fabric design to garment prototype will be beneficial for companies who are willing to save time, labor and cost.

\section{REFERENCES}

[1] Hwang, J.Y., Hahn, K.H., A case study of 2D/3D CAD virtual prototype simulation programs to enhance student performance in student-centered fashion design education, In: Journal of Textile Engineering \& Fashion Technology, 2017, 3, 1, 578-584

[2] Clarke, P., Wilhelm, W., 3D in apparel design: a revolution in the industry, 2011, [Online]. Available: http://www.walterwilhelmassoc.com/news/3D-in-Apparel-Design-A-Revolution-in-the-Industry.cfm

[3] Power, J., Apeagyei, P.R., Jefferson, A.M., Integrating 3D Scanning Data \& Textile Parameters into Virtual Clothing, In: Proceedings of the 2nd International Conference on 3D Body Scanning Technologies, Hometrica Consulting, Lugano, Switzerland, 2011, 213-224. ISBN 978-3-033-03134-0

[4] Durupınar, F., Gudukbay, U., A Virtual Garment Design and Simulation System, [Online]: https://www.researchgate. net/publication/4260995_A_Virtual_Garment_Design_and_Simulation_System

[5] Liu, Y, Zhang, D, Yuen, M.M.,A survey on CAD methods in 3D garment design, In: Computers in Industry, 2010, 61, 6, 576-593

[6] Spahiu, T., Shehi, E., Piperi, E., Personalized avatars for virtual garment design and simulation, In: UNIVERSI International Journal of Education, Science, Technology, Innovation, Health and Environment, Macedonia, 2015, 1, 3

[7] Sayem, A.S.M, Kennon, R., Clarke, N., 3D CAD system for the clothing industry, In: International Journal of Fashion Design, Technology and Education,2010, 3, 2, 45-53

[8] Volino, P., Cordier, F., Magnenat-Thalmann, N., From Early Garment Simulation to Interactive Fashion Design, In: Computer-Aided Design, 2005, 37, 6, 593-608

[9] Ork, N., Mutlu, M., Popescu G., Mocenco A., A study on using 3D visualization and simulation program (Optitex 3D) on leather apparel, In: Annals of the University of Oradea, Fascicle of Textiles, Leatherwork, Oradea, 2016, 16, 2, 191-196

[10] Jevšnik, S., Stjepanović, Z., Celcar, D., Virtual clothes simulations, In: $1^{\text {st }}$ International Conference I Love Inter/ National Fashion, 2009

[11] Harpa, R., Visileanu, E., From fabric design to the dress manufacturing considering the fabric's suitability with the end use, In: Industria Textila, 2018, 69, 6, 434-439, https://doi.org/10.35530/10.35530/IT.069.06.1570

[12] Jevsnik, S., Pilar, T., Stjepanovic, Z., Rudolf, A., Virtual prototyping of garments and their fit to the body, In; DAAAM International scientific book, 2012, 601-618

[13] Fashion in 3D, [Online], Available: https://www.human-solutions.com/vidya/upload/content/weitermachen/ Vidya_Guide_en.pdf

[14] Sungmin, K., Development of a Parametric Design Method for Various Woven Fabric Structures, In: Journal of Engineered Fabrics \& Fibers (JEFF), 2011, 6, 4

[15] Blaga, M., et al., Interactive application for computer aided design of 3d knitted fabrics, In: The 7th International Scientific Conference eLearning and Software for Education, Bucharest, 2011

[16] Indrie, L., Diaz-García, P., Gherghel, S., Development of Jacquard woven fabrics for home decor, In: International Scientific Conference Contemporary Trends and Innovation in the textile industry, 18 May 2018, Belgrade, Serbia, 348-351

[17] Fatahi, I., Yazdi, A.A., Assessment of the relationship between air permeability of woven fabrics and its mechanical properties, In: Surfaces, Fibres and Textiles in Eastern Europe, 2010, 6, 83, 68-71

[18] Peirce, F., The handle of cloth as a measurable quantity, In: Journal of the Textile Institute, 1930, 21, 9, 399 
[19] Allaoui, S., Hivet, G., Wendling, A., Soulat, D., Chatel, S., Experimental Approach for Optimizing Dry Fabric Formability, In: 14th European Conference on Composite Materials, Budapest, Hungary, 2010

[20] Dehkordi, M.T., Nosraty, H., Shokrieh, M.M., Minak, G., Ghelli, D., Low Velocity Impact Properties of Intra-Ply Hybrid Composites Based on Basalt and Nylon Woven Fabrics, In: Materials \& Design, 2010, 31, 8, 3835-3844

[21] Merati, A., Patir, H., Anisotropy in Wrinkle Properties of Woven Fabric, In: The Journal of the Textile Institute, 2011, 102, 7, 639-646

[22] Tohidi, S.D., Jeddi, A., Nosrati, H., Analyzing of the Woven Fabric Geometry on the Bending Rigidity Properties, In: International Journal of Textile Science, 2013, 2, 4, 73-80

\section{Authors:}

\section{LILIANA INDRIE¹, MEHMET METE MUTLU², NILAY ORK EFENDIOGLU²,} SIMONA TRIPA ${ }^{1}$, PABLO DIAZ GARCIA ${ }^{3}$, MIQUEL SOLER ${ }^{4}$

${ }^{1}$ University of Oradea, Faculty of Energy Engineering and Industrial Management, Department of Textiles, Leather and Industrial Management, B.St. Delavrancea 4, Oradea, Romania e-mail: liliindrie@yahoo.com, tripasimona@yahoo.com

${ }^{2}$ Ege University, Engineering Faculty, Department of Leather Engineering, Bornova, Izmir, Turkey e-mail: mete.mutlu@ege.edu.tr, nilay.ork@ege.edu.tr

3Universidad Politécnica de Valencia, Escuela Politécnica Superior de Alcoy, Dpto. Ingeniería Textil y Papelera, Plaza Ferrandiz y Carbonell s/n, 03801 Alcoi, Spain e-mail: pdiazga@txp.upv.es

${ }^{4}$ Centre de Recerca i Transferència de TecnologiaTèxtil de Canet de Mar, Plaça de la Industria, 08360 Canet de Mar, Barcelona, Catalonia, Spain e-mail: solerlm@diba.cat

Corresponding author:

\section{LILIANA INDRIE}

e-mail: liliindrie@yahoo.com 